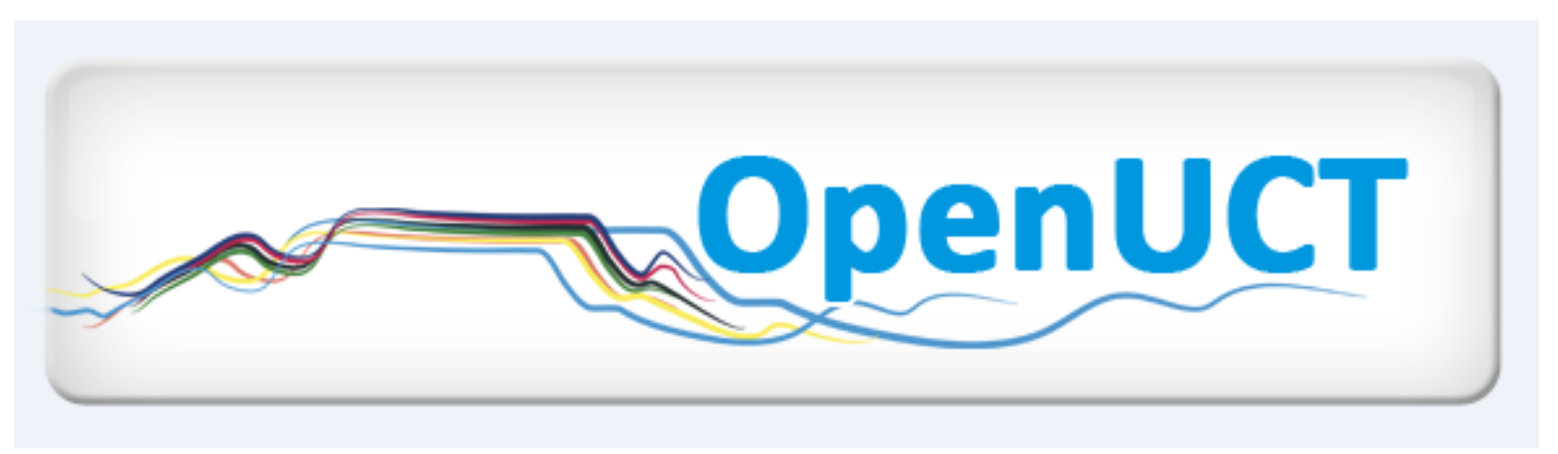

This is the author-approved manuscript version of a journal article published in:

Nassimbeni, M. \& Underwood, P.G. 2007. Two societies: duality, contradictions....and integration: a progress report on South Africa. The International Information \& Library Review. 39(2): 166-173. DOI: $10.1080 / 10572317.2007 .10762744$.

It is made available under the terms of agreement between the author and the journal, and in accordance with the University of Cape Town's Open Access Policy for the purposes of research, teaching and private study.

http://www.openuct.uct.ac.za/sites/default/files/UCTOpenAccessPolicy.pdf 


\title{
Two societies: Duality, contradictions ... and integration: A progress report on South Africa
}

\author{
Mary Nassimbeni, Peter G. Underwood A \\ Centre for Information Literacy, University of Cape Town, Private Bag, Rondebosch 7701, South Africa
}

\begin{abstract}
This paper examines the extent to which the South African Library and Information Science (LIS) agenda maps to the national agenda for the reconstruction and development of the country, which is geared to the elimination of poverty and inequality. The nation has been described as comprising two societies: the one modern and well developed, the other characterised by masses of people living in dire poverty. The mandate of LIS in South Africa includes supporting and stimulating the technological and information development of all communities and providing effective LIS education to meet this goal. The government has embraced the concept of the Information Society, emphasising the link between economic growth and Information and Communication Technologies (ICTs) and has pointed to the need for information literacy education. We present a critique of the fit between LIS policies and practices (including the curriculum) and the needs of an emerging democracy and its development goals, challenged by the duality of globalisation and marginalisation.
\end{abstract}

\section{Introduction}

The pace of change in the library and information profession has been slow since the first South African democratic elections in 1994. After many years of lobbying by the profession, the National Council for Library and Information Services (NCLIS) was legislated into existence in 2001 and inaugurated in 2004. Its establishment is significant because the thinking was that the development of library and information services needed to be coordinated and championed by a statutory body. One of its objects is to "provide optimal access to relevant information to every person in an economic and cost-effective manner' (South Africa, Department of Arts, Culture, Science and Technology, 2001, p. 1). One of the functions of NCLIS is to inform and advise the Minister on the effectiveness of education and training for library and information services. By mid-2005 there were 11,373 libraries in South Africa (South Africa, Government Communication and Information System, 2005, p. 159). Of these, 9416 were school libraries and 1295 were public libraries. University libraries, college libraries, government libraries and special libraries made up the rest.

Twelve years after the first democratic election, NCLIS started working on a Transformation Charter early in 2006. The draft NCLIS Transformation Charter makes the point that libraries, aligned with the vision of the government, can be instrumental in promoting democratic values (Manaka \& Dominy, 2006). The question that suggests itself is, "What is the vision of the government and how can the profession transform itself so as to contribute to the achievement of these goals?" 


\section{Education in change}

The members of the LIS profession are also strongly involved with education, both as recipients of professional education and as information workers alongside academics, researchers and students. It is not surprising to find that the profession has been strongly affected by uncertainties and changes of national policy regarding school and higher education.

The education of LIS practitioners has been affected by the changes which South Africa has undergone in the period following the first democratic elections of 1994 and the formation of a Government of National Unity, followed by two further administrations. In particular, changes to education practice have affected LIS education in two ways: the broader perspective is that of its provision within a changing educational structure; the more narrow view is the way in which the LIS curriculum has changed to reflect societal and technological changes. In this section, the educational structure is briefly examined.

The post-1994 South African government inherited a fractured and dislocated pattern of educational provision that consisted of a mixture of state and private provision, overlain by separation on "racial" lines, a system developed by the former apartheid state. The consequences of this policy were readily apparent, principally in a skewed allocation of resources, largely to the detriment of schools attended by non-white children, and schools in rural areas. The consequences were also manifest in the inadequate provision and training of staff at many schools and the lack of even basic school facilities in many rural areas.

The effects at primary and secondary levels of education resulted in school drop-out rates that were high. It also profoundly affected the quality and preparedness of entrants to higher education, further discouraging participation. Access to higher education and the distribution of resources was similarly skewed along racial lines, to which was added a binary system demarcating "technikon" (technical college) and university education as separate systems, with almost no opportunity for transfer from one system to the other. The participation rate in higher education was low (15\% in 1995).

The overall effect was to produce an education system that was deeply flawed and unable to supply the demand for a skilled and professionally educated population. It provided no base for the entry of South Africa into a democratic culture.

In the period leading up to the first democratic elections of 1994, and in the immediate post-election period, discussions about change and development of policy affecting all levels of education was recognised as the highest priority. The aim was to remedy the inequities in the education system in order to ensure that an affordable compulsory system of primary and secondary education was introduced with adequate safeguards to ensure quality and community consultation. Furthermore, it was recognised that an integrated system of post-secondary education, embracing the concept of lifelong learning, was essential for social healing and economic development. The National Education Policy Investigation (NEPI) of 1992 and the establishment of the Centre for Education Policy Development in 1993 were significant steps towards development of policy and practice to support these aims.

Fixing the higher education system was widely regarded as being of the first priority for economic development. Bunting (2006) has identified and characterised three phases:

"More is better" (1994-1999)

"More is not better" (1999-2004)

"More but different" (2004 to date)

The "More is better" phase centred on the idea that rapid growth of the higher education system would best yield equality of access. The thinking behind this policy of "massification" was developed in the 1996 report of the National Commission on Higher Education but encountered criticism that the economy of South Africa then lacked the resources successfully to undertake such immediate change. The White Paper of 1997 accepted the need for fundamental change and an increase in participation in higher education but adopted, instead, the two goals of achieving financial stability in the higher education system and removing the inefficiencies and duplications inherent 
in the apartheid structure of higher education.

The policy was inadequate, with participation rates in higher education actually declining. Hindsight is proverbially perfect, and it is important to reflect on the difficulties of achieving a massive social transformation coupled with uncertainties over the potential for growth in the South African economy. However, the main cause of failure to achieve an increase in participation rates was attributed to the remaining considerable deficiencies in primary and secondary education.

The second phase identified by Bunting ("More is not better") is marked by the publication in 2001 of a National Plan for Higher Education, which highlighted the need to raise throughput and retention rates in higher education and proposed ways in which these improvements could be achieved. A financial problem gradually became evident: enrolments in higher education had, against expectations, considerably improved but higher education institutions were receiving a lower government subsidy for each student because the funding of higher education was linked to changes in inflation of the money supply and did not take into account the pressure on resources arising from growth in student numbers. Almost in an emergency move, a restriction on student enrolment by each higher education institution was introduced by the Department of Education. The intention was to retain this limit until both increased funding by government could be guaranteed and the resource-base of most institutions considerably improved.

An additional development is highly significant: as part of its strategy of direct intervention in the structure of the higher education system the Ministry of Education enshrined in the National Plan for Higher Education a reconfiguration of the Higher Education Institutions (HEIs), which reduced them from thirty-six to twenty-three. This was achieved by amalgamation of formerly independent HEIs, resulting in an institutional landscape that is characterised by multiple campuses, often at considerable distances from each other. An implicit expectation in the Plan is that all institutions are expected to make much greater use of Information and Communication Technologies (ICTs) in the management and delivery of teaching and learning resources.

The present phase ("More but different') started in an atmosphere of controversy: capping growth is widely perceived as threatening equity of access. It is, indeed, difficult to see how equity could be achieved without substantial and sustained growth in enrolment. Bunting (2006, p.5) comments:

The Department of Education will have to accept that the capping of student enrolments is too blunt an instrument to be employed in a system that is committed to racial and gender equity. The Department will probably move to a new phase of policy in which it accepts the notion of "more but different". This will require the Department to move more firmly towards the 1997 White Paper's goal of a differentiated higher education system.

Thus it can be seen that education policy in South Africa has, and is, suffering from a period of uncertainty and discontinuity, which is making strategic planning quite problematic.

\section{Goals of the emerging democracy in South Africa}

In broad terms the mandate of the government is to transform the country into a democratic state, to correct the injustices and inequalities of the past, to alleviate poverty, and to promote a better life for all. Under this wide rubric, the LIS profession seeks to identify specific niche areas in this reconstruction and development agenda that are appropriate for library and information agencies. The first step is to recognise the enormous disparities between the two societies which live side by side in South Africa. The one is made up of the minority of largely white, affluent people (13\% of the population). The other society consists of $53 \%$ of the population, characterised by poverty and underdevelopment (World Bank, 1999). In this society "half have less than a primary school education, over a third of the children suffer from chronic malnutrition, only a quarter of the house-holds have electricity and running water, and less than a fifth have modern sanitation" (World Bank, 1999). The starkness of the situation is apparent when one considers that the percentage of the population living in absolute poverty (taken to be surviving on a dollar a day) has risen from 4.3 million in 1993 (11.5\%) to 8.6 million people in 2000 (19.8\%) (Hall, 2006).

Frequent references to the information society have been made by government and other leaders especially since the vocal plea by President Mbeki (then Deputy President) at the G7 Information Society Conference in Brussels in 1995. There he urged rich countries to assist poor countries to enjoy the benefits of the information society (Mbeki seeks on-ramp to the information highway, 1995). As a consequence, the Information Society and Development Conference was hosted in South Africa in 1996. The theme of information society has enjoyed prominence ever since 
then in speeches and statements by government leaders. Former Education Minister, Kader Asmal, conceded in a speech in 2002 that the South African government does not have as yet a coherent policy on the information society (Asmal, 2002). He suggested that an information society "involves the integration of the information technology, telecommunications and the information sector" which accompanies the emergence of a new and networked society. He reiterated the government's belief that information communication technologies (ICTs) are "key drivers for economic growth and socio-economic upliftment" (Asmal, 2002). At the inaugural meeting of NCLIS the Deputy Minister of Arts, Culture, Science and Technology advised NCLIS that one of their task would be to "integrate local needs and ideals with those of the global information society"' (Sonjica, 2004).

The Deputy Minister of Education recently made a speech in which he pledged government's commitment to improving the accessibility of ICT to all. He noted that a vast majority of students at school have no access to computers, with only $10 \%$ of the nation's schools enjoying access to the Internet. He acknowledged the role of ICTs in social development and pointed out the need for developing information literacy and bridging the digital divide (Surty, 2005). Other government leaders have bracketed information literacy with the information society which requires a new set of information skills to equip people for the $21^{\text {st }}$ century (Asmal, 2002).

Goldstuck has estimated that in 2005 one in 12 South Africans had access to the Internet, slightly more than the one in 13 at the end of 2003 (Goldstuck, 2005). This is a favourable ratio in comparison to that of the rest of Africa: one in 5000 (Asmal, 2002). The promise of connectivity in schools has not materialised in spite of promises from educational authorities (Goldstuck, 2005).

\section{Libraries from government's perspective}

The Minister of Arts and Culture has pointed to the "revolutionary potential" of libraries and has characterised libraries as "one of the most cost effective and individually empowering tools to create community upliftment and effect social transformation" (Jordan, 2005). Librarians could well take their cue from this powerful statement and examine whether in fact the library has shifted from being the comfortable enclave of middle class white communities to an agency for development (Jordan, 2005).

The Government Communication Information Service puts forward a coherent view of the importance of nformation for development suggesting that the

... public library system could be a focal point in information dissemination to the community. This system can provide facilities for the dissemination efforts of various ministries and agencies to inform and educate the general public as part of individual growth and development"' (South Africa, Task Group on Government Communications 1996).

The statement goes on to recommend that the public library deliver community information services to empower the community, as widely found in the USA. It points out that in re-thinking its role it should also consider how to promote indigenous languages, reflect our diverse cultures, and adapt collection development policies. The report suggests a wide agenda of reform for libraries, including their realignment with other organisations such as community centres. The consequence of reassessing the library's philosophical assumptions is that librarians will need to be re-educated, and the philosophical assumptions need to be reassessed in order to carry out this expanded role (South Africa, Task Group on Government Communications, 1996).

\section{Transforming our libraries}

The ideas underpinning government statements such as these are not foreign to public librarians who would not argue with their validity and desirability. What, then, is the gap between what might be achieved and what is expedient? One of the clearly documented problems has been that public libraries have been suffering from budget cuts that have been eroding their ability to deliver essential services. A submission to a committee of cabinet ministers by the Library and Information Association of South Africa (LIASA) outlined the "internationally accepted strategic role of public/ community libraries in underpinning the fabric of democracy and in the socio-economic development of the country through the development of the 'knowledge society',' and pointed out the extent to which library services were deteriorating as a result of funding problems and governance anomalies owing to changes in national legislation (Library and Information Association of South Africa, 2002). The essence of the governance problem is that in the new 
Constitution of South Africa the public library function was declared to be an exclusive competence of provincial government. Previously this had been a shared responsibility of local and provincial authorities with a division of responsibility and funding. However, there is no legal obligation for local authorities to deliver library services, and the provinces do not have the budget to take over all these services with the consequence that the provinces have an unfunded mandate (Library and Information Association of South Africa, 2002; Anderson, 2005b).

The other source of the gap in perception between what libraries can and should do lies in the constant problem that libraries have of raising their visibility and demonstrating the relevance of their work in nation building. Librarians continue to complain that government does not fully appreciate their role in the information society and their capacity to act as agents of change. This observation is a habitual refrain at conferences and other gatherings. The political reality is, however, that simple assertion of value does not persuade; librarians need to demonstrate impact which is far more difficult to do than merely to reiterate the same claim.

The profession took the first tentative step towards viewing the library as an agent of development when the South frican Institute for Librarianship and Information Science (SAILIS) commissioned a report The Use of Libraries for Development which was published in 1988 (Zaaiman, Roux, \& Rykheer, 1988). The most significant finding of the report was that development agencies and opinion makers were sceptical about the role of the library in development. This is not surprising given the conservative stance of most libraries, indeed their collaborationist relationship with the state (in the view of authoritative researchers such as Merrett, 1994) upholding the status quo of the government at the time that was antagonistic to the development of the majority of the people of South Africa.

The LIS profession is making slow progress towards transformation which requires, as Dick (2002) has pointed out, among other skills, knowledge of the political process. The prevailing philosophical position in the previous political dispensation was that librarianship is neutral and apolitical. This view undoubtedly influenced the curriculum in library schools not associated with liberal universities. As Bell (2002, p. 55) points out, an alternative approach emerged to contest this traditional approach. The principal proposition of the alternative view was the undeniable link between libraries and the struggle for democracy. She also notes that LIS education is engaged in a process of democratisation that in 2001 was far from complete (Bell, 2002, p. 55).

Since Bell's article, the most recent on the status of LIS education, the profession has made a significant political landmark gain, viz. the announcement by the Minister of Arts and Culture that public libraries would receive additional funding of one billion Rand (1 US dollar $=6.90$ Rand). The investment would be accompanied by an investigation into the most effective governance structures for a transformed public library system (R1bn boost for libraries, 2006).

\section{The employment market in Library and information services}

The uncertainties in the higher education sector, and the governance ambiguity in the public library sector, have had a deleterious effect on employment prospects in Library and Information Services because there has been a marked reluctance to extend existing or develop new services and service points. In essence, the prevailing policy has been one of "wait and see" and to cover vacancies by use of temporary staff or by redeployment. Across South Africa, declining numbers have sought entry to professional education programmes, the most probable explanation for which is the limitation in the employment market. Whether there is any associated increase in interest in programmes offering Knowledge and Information Management is presently unclear.

\section{Education for LIS}

The most common route to a professional career is through either a four-year vocationally directed qualification or a postgraduate diploma in library and information science. Lor (2001) points out that there are too many schools, which are among the best in Africa, but mostly lack the critical mass to deliver the sort of education and training currently required. He also points out the need to find ways of recognising prior work experience in keeping with the requirements of the new National Qualifications Framework (Lor, 2001).

Ocholla's survey of LIS education concluded that library schools were "quite cautiously" approaching issues raised by political transformation (Ocholla, 2000,p. 46). Quoting Van Brakel, he identifies the problems that need to be resolved by LIS education: transition to a new democratic dispensation, sharing between formerly advantaged and 
disadvantaged institutions, management of higher education, the difference in quality among LIS qualifications, and rigid undergraduate curriculum structure (Van Brakel, 1997, as quoted by Ocholla, 2000: 45).

Uncertainty also surrounds the degree of specialisation that should characterise the first stages of professional education. Based upon a literature study and interviews with employers, Reagon (2006) contends that a generalist degree in which foundation studies covering collection management, knowledge organisation, services to readers and management, coupled with options in more specialised areas, is still a viable qualification structure for the needs of South African society.

While it is recognised that the staffing of all libraries with suitably qualified professional staff is a desirable aim, it is presently an unrealistic expectation. Davids (2006) comments that "we have a large number of library practitioners who are either unqualified or underqualified y however, most of these practitioners are at times highly competent individuals who acquired their knowledge and skills, about librarianship, through years of practical experience and in-service training." A potential solution is the recognition and accreditation of experiential learning: the South African Qualifications Authority (SAQA) provides scope for this to be done, considering the Recognition of Prior Learning (RPL) to be a priority for the country and of high significance in redressing past injustices (South African Qualifications Authority, 2006).

Information literacy education is certainly in line with government's thinking about the demands of an information society and library schools and libraries have started to develop information literacy programmes and research projects to support the new educational role of the library. Three surveys of information literacy education in South African library schools between 2001 and 2004 found that higher education librarians are increasingly introducing information literacy programmes in their institutions and making the link between their interventions with the concept of 'graduateness', the set of generic critical and analytical skills expected of each graduate (De Jager \& Nassimbeni, 2005, p. 37).

\section{Two societies?}

That librarians have a strong role to play in assisting communities to develop information literacy skills has been a consistent message to the profession at conferences and in the professional literature, and it is a view that has been conveyed to political and community leaders. However, moving beyond rhetoric is sometimes difficult, as Hart (2006) has observed. Her study of Mpumalanga, a largely rural province of South Africa, identified weakness in professional education as restricting the degree to which public librarians felt able to engage with the task of developing skills in the communities they served. This, allied with deficiencies in the infrastructure of many public libraries, hampers attempts at providing a sustained and integrated programme of information literacy education. These findings are also supported by Nassimbeni and May (2006) in a study of the degree of involvement of public libraries in adult education.

Improving access to information and embedding information literacy in the community are endeavours that have the potential to improve the social and economic circumstances of the poor and disadvantaged. An initiative in the Western Cape of South Africa gives some indication of potential: the Smart Cape Project aims to provide free access to computers and the Internet for the citizens of the City of Cape Town using public libraries as the point of service. The evaluation report concludes that the Project "has narrowed the digital divide, provided opportunities for skilled but marginalised youth, enhanced skills and offered access to job opportunities"' (Infonomics South Africa, 2006, p. 55).

Also of significance is the Library Business Corners (2006) project, which aims to use the public library network to provide guidance and information about planning, establishing and running small businesses. The development of microand small businesses is of critical importance for the development of South Africa because, whilst the formal economy of the financial and industrial sectors is the strongest in Africa, it is paralleled by a comparatively weak and underdeveloped informal economy, which again emphasises the "two societies" view of the country. The project has established linkages with other sources of business related information, such as the Business Referral and Information Network (BRAIN) and the Small Enterprises Development Agency (SEDA). The Project started in 1999 in the Western Cape and has established 89 outlets in the public libraries of the Western Cape, with a mixture of metropolitan, provincial and rural sites.

There remains the need for many debates about how the "information society" is to be recognised and developed in South Africa. Providing easy access to information is clearly recognised by the Government of South Africa as an 
important component of a strategy for economic growth and social development. The importance of "grass roots" approaches should not be overlooked in favour of a solely technological view, however. Anderson, in commenting on the affordability of

books in South Africa, notes "the real and urgent issue is that all South Africans should have free and easy access to books through a wide network of well-stocked public libraries" (2005a).

\section{Conclusion}

It can be argued that the thirteen years since the onset of democracy in South Africa is insufficient time to have restructured the education system and adjusted the library system in order to provide or improve access for all. Such transformation has to be viewed in the context of the need to rebuild and develop an economy which, because of sanctions prevalent during the latter part of the apartheid period, lacked responsiveness to the pressures of the free market and coherence. In this and other matters, South Africa is a society still in transition and presently reflecting the effects of many of the divisions that so marked its past.

\section{References}

Anderson, Elisabeth (2005a). Libraries for all! [Online] Available: http://www.centreforthebook.org.za/articles_and_papers/librariesforall.htmlS [10 August 2006]. Anderson, Elisabeth (2005b). Public libraries: A way forward. [Online] Available: http://www.centreforthebook.org.za/articles_and_papers/publiclibrary.htmlS [25 July 2006].

Asmal, Kader (2002). Closing address by Professor Kader Asmal MP, Minister of Education, at the ICTE 2002 conference: Information Society Developments in Education, 5 April 2002. [Online] Available: http://www.info.gov.za/speeches/2002/020408346p1002.htm. [9 August 2006].

Bell, Fiona (2002). Democratisation of South African LIS education: Some causes and effects. Libri, 52(2), 55-66.

Bunting, Ian (2006). The South African case. In Governing access: A four country comparison. Conference hosted by Centre for Higher Education Transformation [CHET], Cape Town, 2-3 March 2006:4-6. [PDF] Available: http://www.chet.org.za/publications/GoverningAccessReport.pdf. [25 July 2006].

Davids, Fadeela (2006). Recognition of prior learning: recognising the skills and abilities of un- and under-qualified librarians. Presentation to the Library Information Services Department by the [Library and Information Association of South Africa] Public and Community Libraries Interest Group (PACLIG), 15 June [Unpublished].

De Jager, Karin, \& Nassimbeni, Mary (2005). Information literacy and quality assurance in South African higher education institutions. Libri, 55(1), 31-38.

Dick, Archie (2002). Five reasons why South African librarianship remains untransformed. nnovation, 25, 27-35.

Goldstuck, Arthur (2005). Great expectations stall on the Internet. 2005. [Online] Available: http://www.theworx.-biz/access05.htmS [1 August 2006].

Hall, Martin (2006). The object of transformation. Keynote address at the Mellon Mays Undergraduate Fellowship Programme Coordinators' Conference, Equity and excellence, Cape Town, January 2006. [Online] Available: www.mmuf.org/pages/scanned/object-transformhall.pdf. [9 August 2006].

Hart, Genevieve (2006). The information literacy education readiness of public libraries in Mpumalanga province (South Africa). Libri, 56(1), 48-62.

Infonomics South Africa. (2006). Smart Cape Access Project: Evaluation of pilot project. [Online] Available: /http://www.smartcape.org.za/smart.pdfS [9 August 2006].

Jordan, Pallo (2005). Address by Minister Pallo Jordan at the fundraising event for the Mdantsane Library Project, Mdantsane. [Online] Available: www.ifo.gov.za/speeches/2005/05112909451001.htm. [10 August 2006].

Library and Information Association of South Africa (LIASA). (2002). The impact of the Municipal Structures Act (no. 117 of 1998 ) on public/community library services in South Africa. Presentation of the President of LIASA, Mr Robert Moropa, to MINMEC (Ministers and Members of the Executive Council), Pretoria, 19 November [Unpublished].

Library Business Corners. (2006). Welcome to LBC. [Online] Available: http://www.lbc.za.net/index-old.htm. [10 August 2006]

Lor, P. (2001). Libraries and librarianship in South Africa: A breathless view. Paper delivered at a workshop of the Western Cape Branch of LIASA to brief a delegation of librarians from Finland, 27 March 2001 [Unpublished].

Manaka, Seth P., \& Dominy, Graham (2006). Library transformation charter draft 2: Charter points identified by Prof S P Manaka, Chairperson: NCLIS, and Dr G A Dominy, National Archivist, during a meeting in Polokwane, 12 January [Unpublished].

Mbeki seeks on-ramp to the information highway. (1995). Business report, 9 March, p. 23.

Merrett, Christopher (1994). A culture of censorship: Secrecy and intellectual repression in South Africa. Cape Town: David Phillip.

Nassimbeni, Mary, \& May, Bev (2006). Adult education in South African public libraries: A profile of activities. South African Journal of Libraries and Information Science, $72(1), 12-26$

Ocholla, D. (2000). Training for library and information studies: A comparative overview of LIS education in Africa. Education for Information, 18(1), 33-52. 
R1bn boost for libraries. (2006). News24.com. [Online] Available: http://www.news24.com/News24/South_Africa/Politics/0,6119,2-7-12_1878896,00.html. [10 February 2006].

Reagon, Renee (2006). Competencies required by South African, entry-level, library and information science graduates. Presentation at a meeting of the Public and Community Libraries Interest Group (PACLIG), 15 June. [Unpublished].

Sonjica, Buyelwa (2004). Speech by Ms Buyelwa Sonjica, Deputy Minister of Arts, Culture, Science and Technology, at the Inaugural Meeting of the National Council for Library and Information Services (NCLIS), Cape Town, Centre for the Book, 11 March. [Online] Available:

http://www.info.gov.-za/speeches/2004/04031209461007.htm. [9 August 2006].

South Africa. Department of Arts, Culture, Science and Technology. (2001). National Council for Library and Information Services Act, Act No. 6, 2001. Cape Town Government Printer.

South Africa. Government Communication and Information System. (2005). Pocket guide to South Africa (3rd ed.). Pretoria: STE Publis hers.

South Africa. Task Group on Government Communications. (1996). Communications 2000: A Vision for Government Communications in South Africa: Final report of the Task Group on Communications to Deputy President Thabo Mbeki. [Online] Available: www.polity.org.za/html/govdocs/commissions/comtask.html. [15 August 2006].

Library Business Corners. (2006). Welcome to LBC. [Online] Available: http://www.lbc.za.net/index-old.htm. [10 August 2006].

Lor, P. (2001). Libraries and librarianship in South Africa: A breathless view. Paper delivered at a workshop of the Western Cape Branch of LIASA to brief a delegation of librarians from Finland, 27 March 2001 [Unpublished].

Manaka, Seth P., \& Dominy, Graham (2006). Library transformation charter draft 2: Charter points identified by Prof S P Manaka, Chairperson: NCLIS, and Dr G A Dominy, National Archivist, during a meeting in Polokwane, 12 January [Unpublished].

Mbeki seeks on-ramp to the information highway. (1995). Business report, 9 March, p. 23.

Merrett, Christopher (1994). A culture of censorship: Secrecy and intellectual repression in South Africa. Cape Town: David Phillip.

Nassimbeni, Mary, \& May, Bev (2006). Adult education in South African public libraries: A profile of activities. South African Journal of Libraries and Information Science, $72(1), 12-26$

Ocholla, D. (2000). Training for library and information studies: A comparative overview of LIS education in Africa. Education for Information, $18(1)$, 33-52.

R1bn boost for libraries. (2006). News24.com. [Online] Available: http://www.news24.com/News24/South_Africa/Politics/0,6119,2-7-12_1878896,00.html. [10 February 2006].

Reagon, Renee (2006). Competencies required by South African, entry-level, library and information science graduates. Presentation at a meeting of the Public and Community Libraries Interest Group (PACLIG), 15 June. [Unpublished].

Sonjica, Buyelwa (2004). Speech by Ms Buyelwa Sonjica, Deputy Minister of Arts, Culture, Science and Technology, at the Inaugural Meeting of the National Council for Library and Information Services (NCLIS), Cape Town, Centre for the Book, 11 March. [Online] Available: http://www.info.gov.-za/speeches/2004/04031209461007.htm. [9 August 2006].

South Africa. Department of Arts, Culture, Science and Technology. (2001). National Council for Library and Information Services Act, Act No. 6, 2001. Cape Town: Government Printer.

South Africa. Government Communication and Information System. (2005). Pocket guide to South Africa (3rd ed.). Pretoria: STE Publishers.

South Africa. Task Group on Government Communications. (1996). Communications 2000: A Vision for Government Communications in South Africa: Final report of the Task Group on Communications to Deputy President Thabo Mbeki. [Online] Available: www.polity.org.za/html/govdocs/commissions/comtask.html. [15 August 2006].

South African Qualifications Authority (SAQA). (2006). Recognition of Prior Learning. [Online] Available:

/http://www.saqa.org.za/show.asp?main=docs/policy/rpl.html\&menu=focurpl. [9 August 2006]

Surty, Enver (2005). Speech by Mr E Surty, Deputy Minister of Education on the occasion of the opening of the Shuttleworth Foundation Tuxlab Roadshow, 9 February 2005. [Online] Available http://www.info.gov.za/speeches/2005/05021809151004.htm. [1 August 2006].

World Bank. (1999). South Africa Country Assistance Strategy: Building a knowledge partnership. [PDF] Available: /http://www-wds.worldbank.org/servlet/WDSContentServer/WDSP/IB/1999/10/07/000094946_99092312090217/Rendered/PDF/multi_page.pdf. [20 May 2006].

Zaaiman, Reginald, Roux, Pieter, \& Rykheer, Johanna (1988). The use of libraries for the development of South Africa: Final Report of an investigation for the South African Institute for Librarianship and Information Science (SAILIS). Pretoria: Centre for Library and Information Services, University of South Africa. 